\title{
The alpha cell expresses glucagon-like peptide-2 receptors and glucagon-like peptide- 2 stimulates glucagon secretion from the rat pancreas
}

\author{
J. de Heer · J. Pedersen $\cdot$ C. Ørskov $\cdot$ J. J. Holst
}

Received: 2 April 2007 / Accepted: 5 June 2007 / Published online: 4 August 2007

(C) Springer-Verlag 2007

\begin{abstract}
Aims/hypothesis Glucagon-like peptide-2 (GLP-2) is a gut hormone regulating intestinal growth and nutrient absorption. Recently, GLP-2 has been reported to stimulate glucagon secretion in healthy humans. We sought to clarify the mechanism and physiological significance of this endocrine effect. Materials and methods The expression of the GLP-2 receptor gene, Glpr2, and the localisation of the protein were evaluated by real-time PCR on cDNA from isolated rat islets and by immunohistochemistry in rat and human pancreas. The glucagon, insulin and somatostatin responses to $0.1,1$ and $10 \mathrm{nmol} / 1 \mathrm{GLP}-2$ and to GLP-1 and GLP-2 given simultaneously were studied in the isolated perfused rat pancreas.

Results Expression of Glp2r transcript was confirmed by PCR. In both human and rat pancreas, GLP-2r immunoreactivity was colocalised with proglucagon. GLP-2 at $10 \mathrm{nmol} / \mathrm{l}$ increased glucagon secretion significantly from a pre-infusion level of $0.314 \pm 0.07$ to $0.508 \pm 0.09 \mathrm{pmol} / \mathrm{min}$ $(p<0.0005)$, whereas lower GLP-2 concentrations were ineffective. Neither insulin nor somatostatin output was
\end{abstract}

Electronic supplementary material The online version of this article (doi:10.1007/s00125-007-0761-6) contains supplementary material, which is available to authorised users.

J. de Heer · J. J. Holst $(\bowtie)$

Department of Medical Physiology, The Panum Institute,

University of Copenhagen,

Blegdamsvej 3,

2200 Copenhagen N, Denmark

e-mail: holst@mfi.ku.dk

J. Pedersen · C. Ørskov

Department of Medical Anatomy, The Panum Institute,

University of Copenhagen,

Copenhagen, Denmark influenced. During simultaneous administration of GLP-1 and GLP-2, net glucagon release was no longer reduced by $0.1,1$ or $10 \mathrm{nmol} / 1$ GLP-1, which, when given alone, inhibited glucagon secretion by $25.0 \pm 9.9,46.2 \pm 4.8$, and $44.1 \pm 2.9 \%$, respectively.

Conclusions/interpretation Our results suggest that GLP-2 stimulates glucagon secretion through GLP-2r present on the alpha cell in rats. In the presence of GLP-2, the glucagonostatic effect of GLP-1, normally co-secreted with GLP-2, is markedly inhibited. Based on our analogous immunohistochemical findings in human pancreas, this mechanism also applies in all likelihood to humans. However, further in vivo studies are required to assess the physiological significance of the glucagonotropic action of GLP-2 in humans.

Keywords Glucagon-like peptide-1

Glucagon-like peptide-2 · GLP-1 · GLP-2 .

Perfused rat pancreas · Insulin · Somatostatin · Glucagon

\section{Abbreviations \\ GLP glucagon-like peptide \\ GLP-2r GLP-2 receptor}

\section{Introduction}

In the past, glucagon-like peptide-2 (GLP-2) has been investigated mainly with regard to its biological effects on the gastrointestinal tract. These effects include stimulation of intestinal mucosal growth and nutrient absorption, inhibition of gastrointestinal motility and gastric acid secretion, and reduction of intestinal permeability [1-4]. Hence, GLP-2 is currently under evaluation as a potential drug candidate for the treatment of gastrointestinal disor- 
ders characterised by mucosal lesions, inflammation or malabsorption $[1,5]$. In addition, GLP-2 has been reported to play a beneficial role in the treatment of osteoporosis, as it has been shown to inhibit bone resorption $[6,7]$.

Both GLP-2 and its structurally related sister peptide, GLP-1, are encoded within the glucagon gene, and are released together from enteroendocrine $\mathrm{L}$ cells in response to nutrient ingestion $[8,9]$. Despite these similarities, the two peptides differ markedly in their action on the endocrine pancreas. Whereas GLP-1 plays a key role in the maintenance of glucose homeostasis and is one of the most potent insulinotropic substances known, GLP-2 has not shown any insulin-releasing properties [10-12]. Consequently therefore, the evaluation of its potential role in modulating the secretion of other islet hormones has been rather neglected. Recently, however, i.v. infusion of GLP-2 has been demonstrated to increase glucagon secretion significantly in healthy, non-obese human subjects [13, 14]. Interestingly, glucose-dependent insulinotropic peptide (GIP), the other hormone thought to function as an incretin hormone, also stimulates glucagon release, whereas GLP-1 potently inhibits glucagon secretion [15-18]. Hence, it is tempting to speculate that the proper regulation of postprandial glucose homeostasis depends not only on the interplay of the incretin hormones GLP-1 and GIP, but also on the contribution of GLP-2 and possibly GIP influencing glucagon secretion.

As both the physiological significance and mechanism of GLP-2's glucagonotropic effect are unknown, we studied the expression of the gene for GLP-2 receptor, Glp2r, and the localisation of GLP-2r by real-time PCR in isolated rat islets and by immunohistochemistry in rat and human pancreas. The influence of GLP-2 alone and in combination with GLP-1 on glucagon secretion was examined in the isolated perfused rat pancreas. In addition, we evaluated the effect of GLP-2 on the secretion of other islet hormones, as both insulin and somatostatin have been implicated in the regulation of glucagon release [19-21].

\section{Materials and methods}

Animals Male Wistar rats (300-375 g, 10-12 weeks old) were purchased from Charles River, Sulzfeld, Germany, more than 1 week before the experiments were performed, and given free access to standard rodent chow and water. Animals were housed two per cage under a $12 \mathrm{~h}$ light-dark cycle. All animal studies were carried out in accordance with international guidelines (National Institutes of Health publication no. 85-23, revised 1985, and Danish legislation governing animal experimentation, 1987) and after approval by the National Superintendence for Experimental Animals.
$R N A$ isolation Rats $(n=3)$ were anaesthetised by injection of pentobarbital $(50 \mathrm{mg} / \mathrm{kg}$ i.p.; Royal Veterinary and Agriculture University, Frederiksberg, Denmark). After perfusion with collagenase type XI (Sigma-Aldrich, Schnelldorf, Germany) through the pancreatic duct to expand the pancreas, the pancreas was quickly removed and pancreatic islets were isolated by further collagenase digestion. Islets were homogenised in $1 \mathrm{ml}$ Tri-reagent (Molecular Research Center, Cincinnati, OH, USA) with a Polytron and by subsequent sonication at $50 \mathrm{~W}$. RNA isolations were carried out according to the manufacturer's protocol. In brief, after $5 \mathrm{~min}$ at room temperature and addition of $100 \mu \mathrm{l}$ 1-bromo-3-chloropropane, the homogenates were vigorously vortexed, and thereafter kept for $15 \mathrm{~min}$ at room temperature before centrifugation at $12,000 \times g$ for $15 \mathrm{~min}$ at $4^{\circ} \mathrm{C}$. After transfer of the aqueous phases to fresh tubes and addition of $500 \mu \mathrm{l}$ isopropanol, samples were left at room temperature for $10 \mathrm{~min}$ and thereafter centrifuged at $12,000 \times \mathrm{g}$ for $8 \mathrm{~min}$ at $4^{\circ} \mathrm{C}$. The pellets were washed in $1 \mathrm{ml} 75 \%$ ethanol and collected by centrifugation at $7,500 \times \mathrm{g}$ for $5 \mathrm{~min}$ at $4^{\circ} \mathrm{C}$. Pellets were airdried, dissolved in $30 \mu \mathrm{l} \mathrm{H}_{2} \mathrm{O}$ and incubated for $10 \mathrm{~min}$ at $60^{\circ} \mathrm{C}$. The RNA concentrations were determined by absorbance measurements at 260 and $280 \mathrm{~nm}$, and samples were stored at $-80^{\circ} \mathrm{C}[22]$.

DNase treatment and cDNA synthesis Prior to cDNA synthesis, the RNA samples were treated with Turbo DNAfree DNase (Ambion, Austin, TX, USA) according to the manufacturer's protocol. In brief, $10 \mu \mathrm{g}$ RNA was incubated with 4 IU DNase for $1 \mathrm{~h}$ at $37^{\circ} \mathrm{C}$. DNase was inactivated by adding inactivation reagent. cDNA was synthesised using a Fermentas Revertaid cDNA synthesis kit (Fermentas International, Burlington, Ontario, Canada). In brief, DNase-treated RNA and oligo(dT) primers were incubated for $5 \mathrm{~min}$ at $70^{\circ} \mathrm{C}$, and, after addition of buffer, RNase-inhibitor and dNTPs, for $5 \mathrm{~min}$ at $37^{\circ} \mathrm{C}$. Thereafter, reverse transcriptase was added and samples were incubated for $1 \mathrm{~h}$ at $42^{\circ} \mathrm{C}$ and for $10 \mathrm{~min}$ at $70^{\circ} \mathrm{C}$. The cDNA samples were stored at $-20^{\circ} \mathrm{C}$ until expression analysis.

Real-time PCR Real-time PCR expression analysis was carried out using a Stratagene MX3000P real-time PCR system (Stratagene, La Jolla, CA, USA) and Finnzymes DyNAmo(tm) HS SYBR(r) Green qPCR kit (Finnzymes, Woburn, MA, USA) with following thermal profile: $95^{\circ} \mathrm{C}$ for $15 \mathrm{~min}, 45$ cycles at $95^{\circ} \mathrm{C}$ for $10 \mathrm{~s}, 60^{\circ} \mathrm{C}$ for $20 \mathrm{~s}$ and $72^{\circ} \mathrm{C}$ for $30 \mathrm{~s}$ with fluorescence collection, $95^{\circ} \mathrm{C}$ for $1 \mathrm{~min}, 55^{\circ} \mathrm{C}$ for $30 \mathrm{~s}$ followed by a ramp to $95^{\circ} \mathrm{C}$ with fluorescence collection.

Primers were designed in Beacon Designer version 4.00 (Premier Biosoft International, Palo Alto, CA, USA). Sequences and concentrations of the primers used are available as Electronic Supplementary Material Table 1. 
The most stably expressed housekeeping genes in islets and proximal intestine were identified in a pilot study comparing the expression of a panel of housekeeping genes in islets and intestine. The results were subsequently analysed using the software Genorm [23], and succinyldehydrogenase subunit A (Sdha), tyrosine 3-monooxygenase/tryptophan 5-monooxygenase activation protein, zeta polypeptide (Ywhaz), and TATA box binding protein ( $T b p)$ were chosen for normalisation.

The expression levels of Sdha, Ywhaz, Tbp, glucagon ( Gcg) and Glp2r were analysed in cDNA from isolated islets and proximal intestine. The expected size of the PCR products was confirmed by gel electrophoresis. The relative expression of the Glp2r and $G c g$ genes in islets compared with proximal intestine was calculated as described [24], with the exception that the expression of $G l p 2 r$ and $G c g$ was normalised to the geometric mean of the expression of the three housekeeping genes.

Immunohistochemistry Paraffin-embedded sections of rat and human pancreas (archival human tissues collected during the 1970s) were subjected to antigen retrieval using citrate buffer as described in [25]. GLP-2r antibody 99077 was diluted 1:40,000 and proglucagon antibody F1 was diluted 1:5,000. Specific GLP-2r antibody binding in the tissue was visualised using biotin-labelled anti-rabbit antibody and the tyramide signal amplification kit as described by the manufacturer (Roche, Basel, Switzerland), followed by streptavidin coupled to Texas Red (Amersham, Uppsala, Sweden). Specific binding of the proglucagon antibody F1 was visualised using digoxigenin-labelled antimouse antibody followed by fluorescein-labelled antidigoxigenin antibody as described in [25].

Isolated perfused rat pancreas Non-fasted rats were anaesthetised by i.p. injection of pentobarbital $(50 \mathrm{mg} / \mathrm{kg})$, and the pancreas was dissected and perfused in situ as described in [21]. Briefly, the rat was killed by removal of the heart and the pancreas was perfused in a single-pass system through both the coeliac and the superior mesenteric artery via a catheter inserted into the adjacent abdominal aorta. All other aortic branches were ligated. The venous effluent was collected, except for the first $20 \mathrm{~min}$ of the equilibration period, for periods of $1 \mathrm{~min}$ via an obstructing cannula inserted into the portal vein, and stored at $-20^{\circ} \mathrm{C}$ until analysis. The flow rate was kept constant at $4 \mathrm{ml} / \mathrm{min}$. The perfusion medium consisted of a modified Krebs-Ringer bicarbonate buffer containing, in addition, $0.1 \%$ human serum albumin (Behringwerke, Marburg, Germany), 5\% dextran T-70 (Pharmacia Biotech, Uppsala, Sweden), $3 \mathrm{mmol} / 1$ glucose and $5 \mathrm{mmol} / \mathrm{l}$ each of pyruvate, fumarate and glutamate. The perfusion medium was continuously gassed with a $95 \% \mathrm{O}_{2} / 5 \% \mathrm{CO}_{2}$ mixture to achieve $\mathrm{pH} 7.4$, and maintained at $37^{\circ} \mathrm{C}$ during the entire experiment. Human recombinant GLP-2(1-33) (a generous gift from Novo Nordisk, Bagsværd, Denmark) was dissolved in PBS with 5\% Haemaccel (Behringwerke) and infused into the arterial line using a syringe pump to give final perfusate concentrations of $0.1,1$ and $10 \mathrm{nmol} / \mathrm{l}$. Synthetic GLP-1(7-37) (a generous gift from Novo Nordisk) was dissolved in $0.9 \%$ $\mathrm{NaCl}$ containing $1 \%$ human serum albumin. Its authenticity was confirmed by amino acid analysis, analytical reversedphase HPLC and plasma desorption mass spectrometry, and its purity was shown to be $>99 \%$ by HPLC with detection at $214 \mathrm{~nm}$. The final concentrations of GLP-1 in the perfusate were $0.1,1$ and $10 \mathrm{nmol} / \mathrm{l}$. L-Arginine hydrochloride (SigmaAldrich, Steinheim, Germany) was dissolved in perfusion medium to give a final perfusate concentration of either 7.5 or $10 \mathrm{mmol} / 1$

Experimental protocol All experiments started with a 35 min equilibration period, during which only basal perfusion medium ( $3 \mathrm{mmol} / 1$ glucose) was infused. In concentrationresponse experiments $(n=8), 0.1,1$ and $10 \mathrm{nmol} / 1$ GLP-2 were administered for $15 \mathrm{~min}$ each. Each administration of GLP-2 was followed by a 15 min period of perfusion with basal medium only to allow hormone secretion to stabilise. In a second set of experiments $(n=6), 0.1 \mathrm{nmol} / 1$ GLP-1, $1 \mathrm{nmol} /$ 1 GLP-1 and $10 \mathrm{nmol} / 1$ GLP-2 were administered alone followed by the simultaneous infusion of $0.1 \mathrm{nmol} / 1 \mathrm{GLP}-1+$ $10 \mathrm{nmol} / \mathrm{l} \mathrm{GLP}-2$ and $1 \mathrm{nmol} / \mathrm{l}$ GLP-1 + $10 \mathrm{nmol} / \mathrm{l}$ GLP-2. In a third set of experiments $(n=7)$, the same protocol was followed, except that GLP-2 was infused first, followed by $0.1 \mathrm{nmol} / 1 \mathrm{GLP}-1$ and $1 \mathrm{nmol} / \mathrm{l} \mathrm{GLP}-1$. In a fourth set of experiments $(n=3), 10 \mathrm{nmol} / \mathrm{l}$ GLP-1 and $10 \mathrm{nmol} / \mathrm{l}$ GLP-2 were first given alone and thereafter in combination, and in another set $(n=3)$, the same protocol was followed, except that GLP-2 was administered first, followed by GLP-1. Each administration lasted for $10 \mathrm{~min}$ and was followed by a $15 \mathrm{~min}$ rest period. L-Arginine at either 7.5 or $10 \mathrm{mmol} / \mathrm{l}$ was infused for $5 \mathrm{~min}$ to monitor the responsiveness of the pancreas.

Hormone analysis Pancreatic insulin, glucagon and somatostatin concentrations in venous effluent were analysed by RIA. Insulin concentrations were determined using guinea pig antiserum raised against porcine insulin (2006-3), which cross-reacts strongly with both rat insulin I and II, and human ${ }^{125} \mathrm{I}$-labelled insulin labelled at position A14. A mixture (2:1) of rat insulin I and II was used as standard (Novo Nordisk) [26]. Glucagon immunoreactivity was measured using highly purified porcine glucagon as standard and the C-terminally directed antiserum 4305, which mainly detects glucagon of pancreatic origin [27]. Somatostatin immunoreactivity was determined using rabbit antiserum 1758 , raised against synthetic cyclic somatostatin, recognising both somatostatin-14 and somatostatin-28 [28]. 


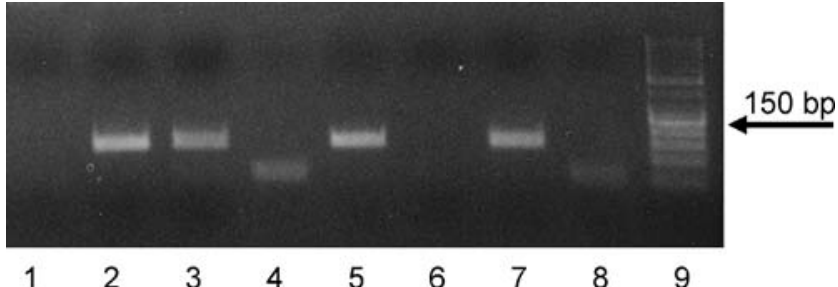

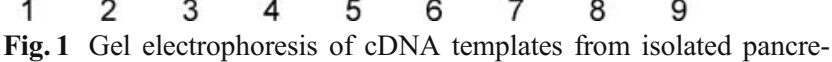
atic rat islets and proximal rat intestine. Expression of Glp2r transcript was confirmed by a PCR product of the expected length of $142 \mathrm{bp}$ in proximal intestine (lane 2) and isolated pancreatic islets (lanes 3, 5, 7). Lane 1, no template control; lanes 4, 6, 8, no reverse transcriptase controls; lane 9, RNA marker. Lanes 3 and 4, 5 and 6, and 7 and 8 represent three separate experiments. Based on the melt curve analysis and the respective threshold cycle value (data not shown), the low molecular mass band in lane 4 was considered a primer-dimer product and hence had no influence on determination of the relative expression value

Calculations and statistical analysis Results are reported as mean value $\pm \mathrm{SEM}$ in $\mathrm{pmol} / \mathrm{min}$ or $\mathrm{fmol} / \mathrm{min}$ or percentage of prestimulatory secretion for indicated numbers of experiments. Statistical evaluation consisted of ANOVA followed by Bonferroni correction for multiple comparisons and the two-tailed $t$ test for paired data of mean hormone outputs of prestimulatory (the $5 \mathrm{~min}$ period immediately preceding initiation of infusion), stimulatory (the $5 \mathrm{~min}$ period after initiation of infusion with omission of the first $2 \mathrm{~min}$ ) or inhibitory periods (the $5 \mathrm{~min}$ period before the end of infusion). Statistica version 7.0 (StatSoft, Tulsa, OK, USA) was used and $p$ values $<0.05$ were considered significant.

\section{Results}

GLp2r expression and localisation Expression of Glp2r transcript was revealed by real-time PCR on cDNA from isolated pancreatic rat islets. The result was verified by demonstration of a PCR product of the expected length of 142 bp (Fig. 1). The relative expression levels of Glp2r and Gcg transcripts in rat islets compared with proximal intestine were $0.73 \pm 0.15$ and $947 \pm 126$, respectively.

By immunohistochemistry, we found GLP-2 $r$ to be present in both human (Fig. 2a) and rat pancreas (Fig. 2d and g). Immunohistochemical double staining with GLP-2r antibody revealed that GLP-2r immunoreactivity was localised to cells which were also immunoreactive to monoclonal proglucagon antibody F1 in human (Fig. 2b,c) and rat pancreas (Fig. 2e,f and h,i). Immunohistochemical double staining for GLP-2r and insulin and for GLP-2r and somatostatin did not show any colocalisation (data not shown).

Isolated perfused pancreas studies In the perfused rat pancreas, infusion of $10 \mathrm{nmol} / \mathrm{l} \mathrm{GLP}-2$ increased glucagon secretion significantly from a prestimulatory level of $0.314 \pm$
Fig. 2 GLP-2 receptors are colocalised with proglucagon in the endocrine pancreas of human and rat. Sections of human $(\mathbf{a}-\mathbf{c})$ and rat $(\mathbf{d}-\mathbf{i})$ pancreas were double-stained using GLP2 receptor antibody 99077 (red; a, $\mathbf{d}, \mathbf{g})$ and proglucagon antibody F1 (green; b, e, h). Yellow fluorescent cells $(\mathbf{c}, \mathbf{f}, \mathbf{i})$ represent cells immunoreactive for both antibodies
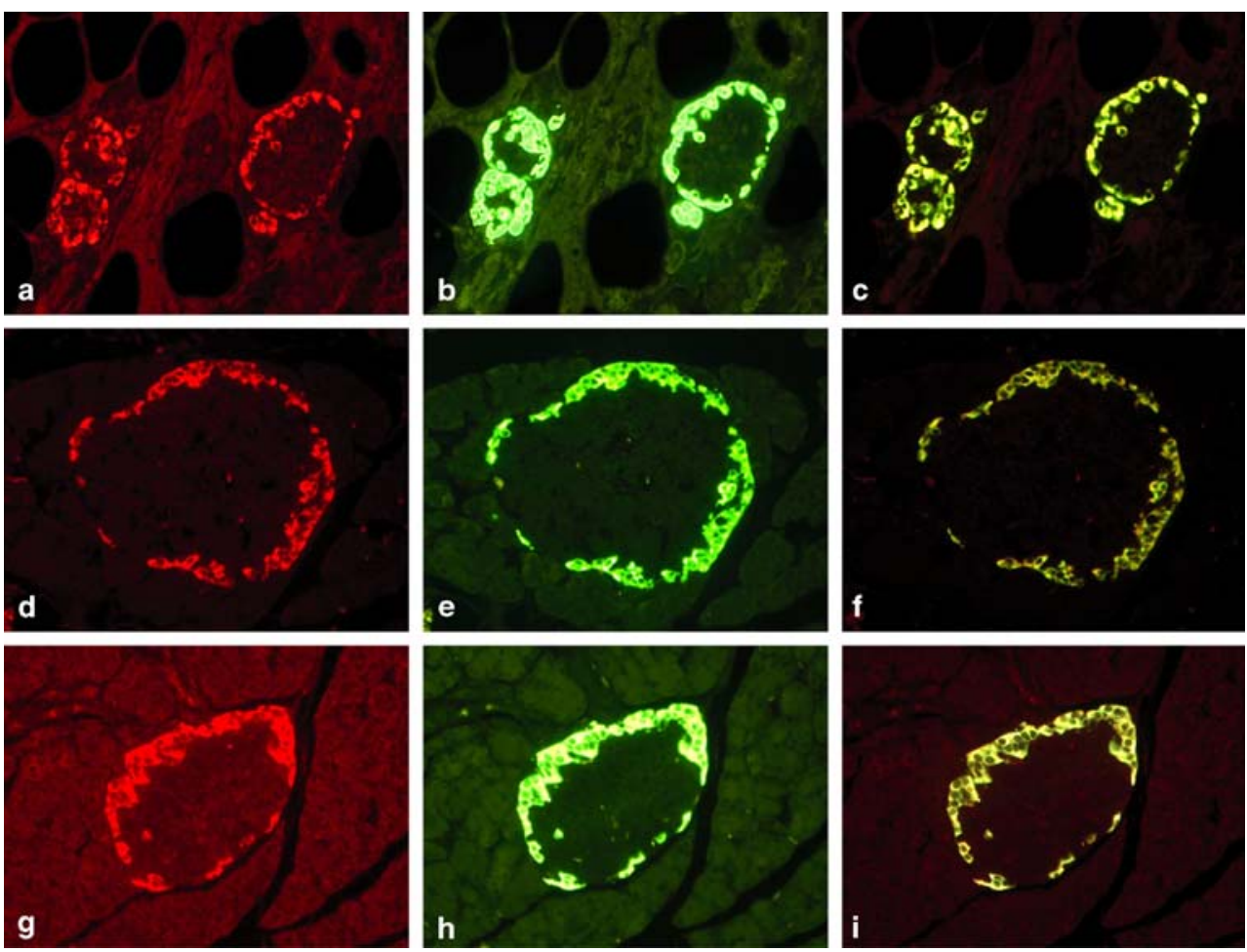
0.07 to $0.508 \pm 0.09 \mathrm{pmol} / \mathrm{min}(p<0.0005)$, whereas at GLP2 concentrations of 0.1 and $1 \mathrm{nmol} / 1$ no effect on glucagon secretion was observed (Fig. 3). Neither somatostatin nor insulin output was influenced by infusion of $0.1,1$ or $10 \mathrm{nmol} / \mathrm{l}$ GLP-2 (data not shown).

To study the effect of GLP-1 on GLP-2-induced glucagon secretion, further perfusion experiments were performed in which GLP-1 at 0.1, 1 and $10 \mathrm{nmol} / 1$ and GLP-2 at $10 \mathrm{nmol} / 1$ were first infused alone and subsequently combined. In experiments in which GLP-1 infusions were given first, single infusions of 0.1 and $1 \mathrm{nmol} / 1$ GLP-1 inhibited glucagon secretion by $15.1 \pm 7.4 \%$ (from $0.347 \pm 0.032$ to $0.291 \pm 0.032 \mathrm{pmol} / \mathrm{min} ; p=\mathrm{NS}$ ) and $51.0 \pm 6.8 \%$ (from $0.363 \pm$ 0.059 to $0.176 \pm 0.033 \mathrm{pmol} / \mathrm{min} ; p<0.01$; Fig. 4a) respectively, and in experiments in which GLP-2 was infused first inhibition was $34.9 \pm 6.3 \%$ (from $0.354 \pm 0.04$ to $0.232 \pm$ $0.036 \mathrm{pmol} / \mathrm{min} ; p<0.005)$ and $41.4 \pm 5.0 \%(0.31 \pm 0.072$ to $0.17 \pm 0.033 \mathrm{pmol} / \mathrm{min} ; p<0.05$ ) respectively (Fig. $4 \mathrm{~b}$ ). However, when 0.1 and $1 \mathrm{nmol} / 1$ GLP-1 and $10 \mathrm{nmol} / 1$ GLP-2 were given combined, the glucagonostatic effect of GLP-1 was neutralised and the glucagonotropic action of GLP-2 prevailed. Accordingly, the glucagon responses to GLP-2 infused alone and to GLP-1 and GLP-2 given simultaneously did not differ from each other. This finding was irrespective of whether experiments started with single infusions of GLP-1 or GLP-2.

Infusion of $10 \mathrm{nmol} / \mathrm{l}$ GLP-1 alone inhibited glucagon release by $47.0 \pm 5.5 \%$ (from $0.526 \pm 0.077$ to $0.280 \pm$ $0.052 \mathrm{pmol} / \mathrm{min} ; p<0.05$; GLP-1 infused first; Fig. 5a) and by $41.2 \pm 4.0 \%(0.513 \pm 0.035$ to $0.304 \pm 0.039 \mathrm{pmol} /$ min; $p<0.005$; GLP-2 infused first; Fig. 5b).

However, the stimulatory effect of GLP-2 was sufficient to overcome the inhibitory effect of GLP-1 when the two peptides were co-infused in equimolar $(10 \mathrm{nmol} / \mathrm{l})$ concentrations. Thus, there was no reduction in glucagon levels compared with pre-infusion levels in response to simultaneous infusion of GLP-1 and GLP-2; rather, levels

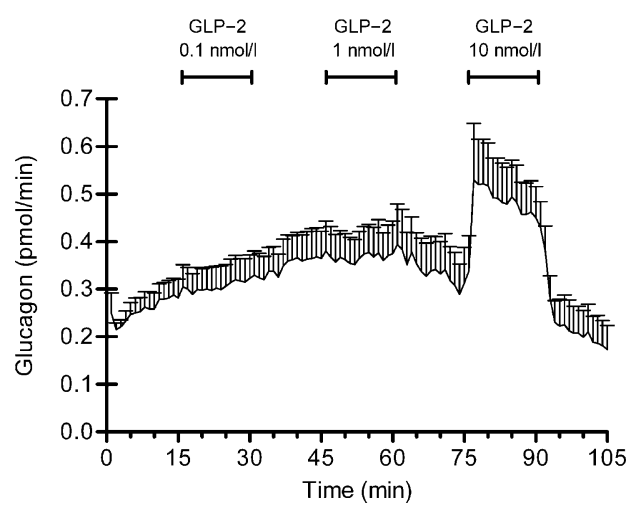

Fig. 3 Glucagon secretion from the perfused rat pancreas in response to $0.1-10 \mathrm{nmol} / 1 \mathrm{GLP}-2$ during perfusion with $3 \mathrm{mmol} / 1$ glucose $(n=8)$. Data are mean \pm SEM
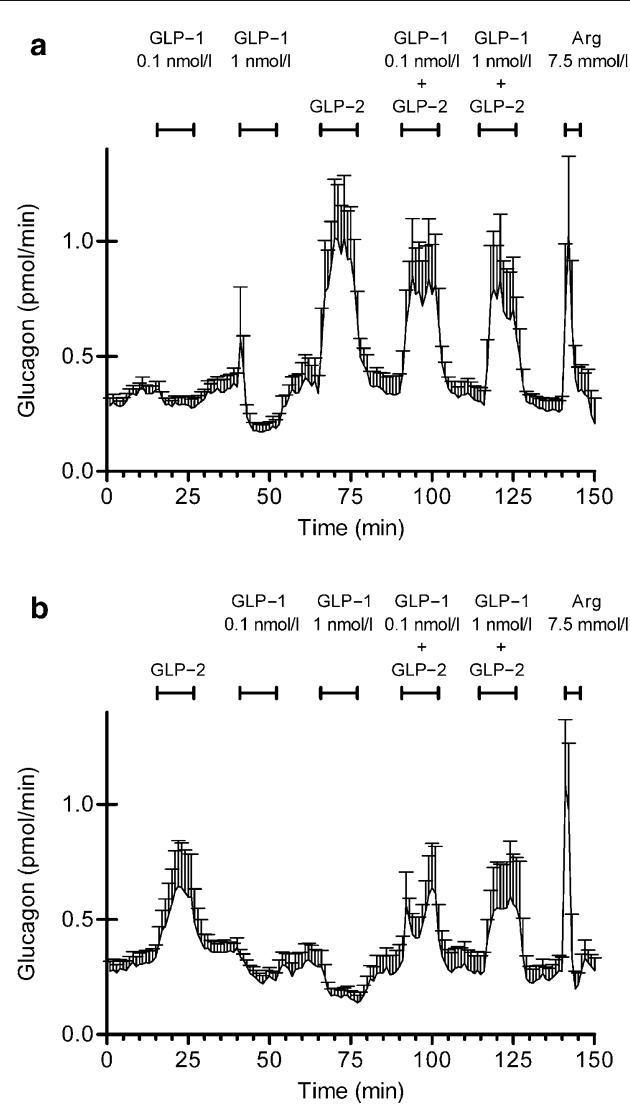

Fig. 4 Glucagon secretion from the perfused rat pancreas in response to a GLP-1 $(0.1$ and $1 \mathrm{nmol} / \mathrm{l})$ alone, GLP-2 $(10 \mathrm{nmol} / \mathrm{l})$ alone and GLP-2 $(10 \mathrm{nmol} / \mathrm{l})$ together with GLP-1 $(0.1$ and $1 \mathrm{nmol} / \mathrm{l})$, $n=6$, and b GLP-2 (10 nmol/l) alone, GLP-1 (0.1 and $1 \mathrm{nmol} / \mathrm{l})$ alone and GLP-2 (10 nmol/l) together with GLP-1 (0.1 and $1 \mathrm{nmol} / \mathrm{l}), n=7$. Perfusion was at $3 \mathrm{mmol} / \mathrm{l}$. Data are mean \pm SEM. Arg Arginine

remained unchanged (Fig. 5a) or even increased (Fig. 5b) during the combined infusions.

In agreement with concentration-response studies, infusion of GLP-2 did not influence somatostatin secretion. In contrast, GLP-1 increased somatostatin output from a basal level of $18.7 \pm 2.3$ to $26.7 \pm 2.8 \mathrm{fmol} / \mathrm{min}(0.1 \mathrm{nmol} / 1 ; p<$ $0.05)$ and $34.0 \pm 3.9(1 \mathrm{nmol} / 1 ; p<0.0001$; Fig. 6) respectively, and from $24.0 \pm 1.6$ to $46.7 \pm 4.1 \mathrm{fmol} / \mathrm{min}(10 \mathrm{nmol} / \mathrm{l}$; $p<0.05$; data not shown; all experiments starting with infusion of GLP-1). The stimulatory effect of GLP-1 on somatostatin secretion was not influenced by co-infusion of GLP-2 and no significant difference between the somatostatin response to GLP-1 infused alone and to GLP-1 infused in combination with GLP-2 was detectable.

\section{Discussion}

So far, studies of the gut hormone GLP-2 have mainly focused on its actions on the gastrointestinal tract and bone, where it is involved in the regulation of intestinal growth and nutrient 
absorption, and the inhibition of bone resorption. In contrast to GLP-1, which exerts its main effects on the pancreas, GLP2 was thought not to influence pancreatic endocrine secretion. Recent findings suggest that this may not be true. Evaluating the effect of GLP-2 on appetite and energy intake, Sorensen et al. first demonstrated a glucagonotropic effect of GLP-2 in healthy human subjects [13]. Meier et al. [14] made similar observations and, in addition, reported that GLP-2 enhances lipid absorption and inhibits gastric acid secretion in humans. However, the mode of action by which GLP-2 stimulates glucagon secretion remained unclear, as did the physiological importance of this effect.

In this study, we further studied the underlying mechanism of GLP-2's glucagonotropic effect in the rat. In addition, we examined the impact of simultaneous infusion of GLP-1 and GLP-2, because, under physiological circumstances, the two hormones are secreted in parallel from $L$ cells in response to nutrient intake. Our experiments in the in situ perfused pancreas showed that GLP-2 increases glucagon secretion also in rats, and that administration of the glucagonotropic GLP-2 markedly inhibited the glucagonostatic effect of GLP-
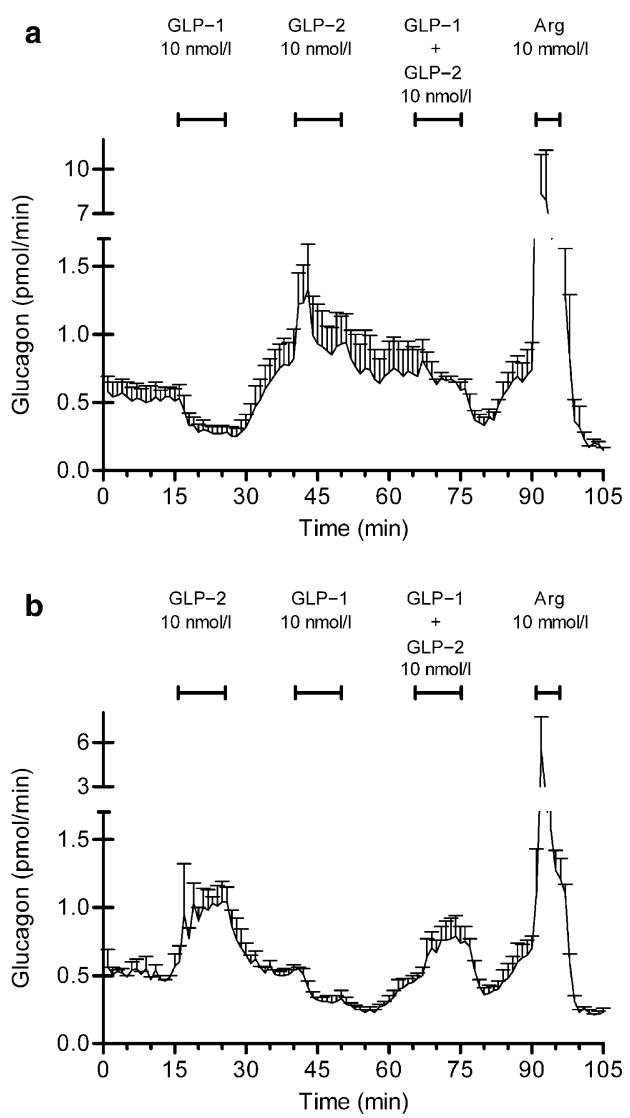

Fig. 5 Glucagon secretion from the perfused rat pancreas in response to a GLP-1 $(10 \mathrm{nmol} / \mathrm{l})$ alone, GLP-2 $(10 \mathrm{nmol} / \mathrm{l})$ alone and GLP-2 $(10 \mathrm{nmol} / \mathrm{l})$ together with GLP-1 $(10 \mathrm{nmol} / \mathrm{l}), n=3$; and b GLP-2 (10 nmol/l) alone, GLP-1 (10 nmol/l) alone, and GLP-2 (10 nmol/l) together with GLP-1 $(10 \mathrm{nmol} / \mathrm{l}), n=3$. Perfusion was at $3 \mathrm{mmol} / \mathrm{l}$. Data are mean \pm SEM. Arg Arginine

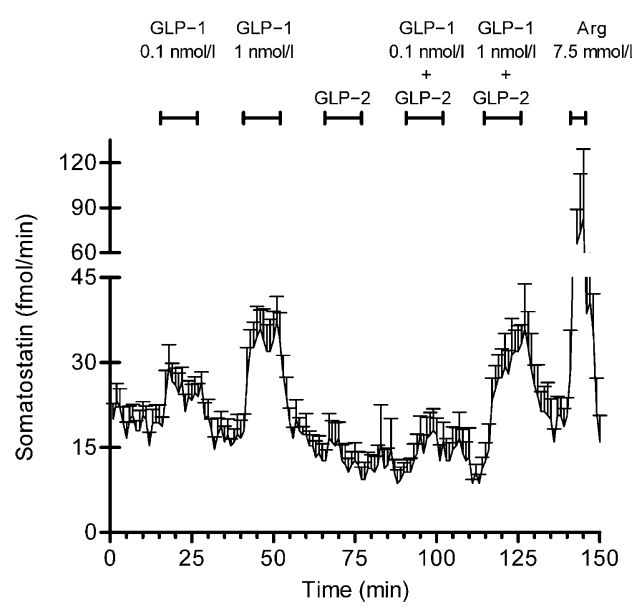

Fig. 6 Somatostatin secretion from the perfused rat pancreas in response to GLP-1 $(0.1$ and $1 \mathrm{nmol} / \mathrm{l})$ alone, GLP-2 $(10 \mathrm{nmol} / \mathrm{l})$ alone and GLP-2 $(10 \mathrm{nmol} / \mathrm{l})$ together with GLP-1 $(0.1$ and $1 \mathrm{nmol} / \mathrm{l}), n=6$. Perfusion was at $3 \mathrm{mmol} / \mathrm{l}$. Data are mean \pm SEM. $\operatorname{Arg}$ Arginine

1. By real-time PCR and immunohistochemistry, we found Glp2 $r$ to be expressed in isolated pancreatic rat islets and the protein to be localised to alpha cells of both human and rat pancreas, which, to our knowledge, is a novel finding. Taken together, these results suggest that GLP-2 exerts its glucagonotropic effect via GLP-2r present on the alpha cell.

Consistent with the findings by Sorensen et al. [13] and Meier et al. [14], GLP-2 at a dose of $10 \mathrm{nmol} / \mathrm{l}$ significantly stimulated glucagon secretion in the perfused rat pancreas, whereas 0.1 and $1 \mathrm{nmol} / 1$ were ineffective. Also in line with these studies, no effect of GLP-2 on insulin secretion was observed. It is well established that somatostatin inhibits glucagon secretion in the endocrine pancreas, and we have recently shown that GLP-1 mediates its inhibitory effect on the pancreatic alpha cell through somatostatin acting on somatostatin receptor subtype 2 (J. de Heer, D. H. Coy, J. J. Holst, unpublished results) [19-21]. However, in the present study the release of somatostatin was unaltered in response to GLP-2. These findings support the idea of a direct receptor-mediated effect of GLP-2 on glucagon secretion, whereas an involvement of insulin or somatostatin appears rather unlikely.

GLP-2 acts through a specific G protein-coupled receptor, which is closely related to the receptors for glucagon, GLP-1 and GIP, but does not show any binding affinity for these ligands [29]. The rat GLP-2 $r$ has been identified so far in the gastrointestinal tract, brain and lung [25, 29-31]. In line with our notion of a direct action of GLP-2, expression analysis by real-time PCR in isolated rat islets clearly showed that $G l p 2 r$ is also expressed in the endocrine pancreas. The expression level was comparable to that observed in the proximal intestine, which, in view of GLP-2's potent effects on the intestine, might point to a role of GLP-2 in the endocrine pancreas. By contrast, our results disagree with findings by Yusta et al. [30], who failed to detect Glp2r 
mRNA transcripts in pancreatic mouse tissue and rat insulinoma cell lines. One possible reason for this difference might be the use of freshly isolated islets for mRNA isolation in our study, which, by the elimination of exocrine tissue, leads to a lesser degree of RNase activity and RNA degradation, and consequently better RNA purification.

However, the conclusion that GLP-2 exerts its glucagonotropic effect through receptors present on the alpha cell must be drawn with caution, because real-time PCR was performed on isolated islets and not on isolated alpha cells. Thus, we cannot exclude the possibility that Glp2r detected by PCR originated from other islet cells instead. However, the finding that, in contrast to glucagon release, neither insulin nor somatostatin secretion was influenced by GLP-2 infusion argues against this notion. In addition, our immunohistochemical results in both rat and human pancreas showing co-localisation of immunoreactivities for GLP-2 $r$ and proglucagon provide further evidence supporting the presence of GLP-2r on alpha cells. The absence of GLP-2r, as judged by immunohistochemistry, in beta and delta cells is consistent with the lack of effect of GLP-2 on the secretion of insulin and somatostatin.

Considering the high GLP-2 concentration required (10 $\mathrm{nmol} / \mathrm{l})$ to induce a stimulatory effect on glucagon release in the perfused rat pancreas, one might speculate that the effect observed is of only minor, if any, physiological importance in the rat. In humans, by contrast, Sorensen and co-workers [13] infused a rather low GLP-2 concentration of 0.42 pmol min ${ }^{-1} \mathrm{~kg}^{-1}$, which resulted in physiological GLP-2 plasma concentrations of $62 \pm 4 \mathrm{pmol} / 1$, and they detected significant, although modest, increments in glucagon release; and Meier et al. [14] reported marked increases in glucagon secretion in response to pharmacological GLP2 concentrations ( 2 pmol min ${ }^{-1} \mathrm{~kg}^{-1}$ ), leading to GLP-2 plasma levels of $208 \pm 8 \mathrm{pmol} / \mathrm{l}$ [32]. It is a general experience that the responsiveness of isolated organs and tissues studied in vitro is reduced, and thus higher doses are required in these preparations than in in vivo experiments. Accordingly, the GLP-1 concentrations used in this study exceeded plasma levels of GLP-1 in humans by $\sim 100$ - to $\sim 1,000$-fold [33]. Thus, based on the present data, we cannot deduce to what extent the glucagonotropic effect of GLP-2 is of physiological significance in the rat. Interestingly, in neither of the two human studies could concomitant changes in plasma glucose concentrations be observed. To examine whether the glucagonotropic effect of GLP-2 was influenced by GLP-1, which potently inhibits glucagon secretion [15-17], we administered both peptides simultaneously, and found that GLP-2 eliminated the inhibitory effect of 0.1 and $1 \mathrm{nmol} / \mathrm{l} \mathrm{GLP}-1$ on glucagon release and markedly attenuated that of $10 \mathrm{nmol} / 1$ GLP-1. One might argue that our findings from experiments in which 0.1 and $1 \mathrm{nmol} / \mathrm{l} \mathrm{GLP}-1$ were co-infused with $10 \mathrm{nmol} /$
1 GLP-2 do not reflect the normal ratio of GLP-1 and GLP-2 concentrations, as the two peptides are co-secreted in equimolar amounts from L cells. However, since GLP-1 is degraded more quickly than GLP-2 $\left(t_{1 / 2}\right.$ for GLP-1 is $\sim 1-$ $2 \mathrm{~min}$ [34] and $7 \mathrm{~min}$ for GLP-2 [35]), the alpha cell is normally exposed to lower concentrations of GLP-1 than GLP-2.

The glucagon response in experiments with combined infusion of $10 \mathrm{nmol} / 1$ GLP-1 and GLP-2 remained unchanged when GLP-1 was infused first (Fig. 5a), whereas it was increased when GLP-2 was administered first (Fig. 5b). The explanation for this is not obvious. However, it has to be emphasised that in none of the four different sets of experiments was the glucagonostatic effect of GLP-1 strong enough to induce a fall in net glucagon secretion, when it was co-administered with GLP-2. This phenomenon, together with the stimulatory actions of GIP, could explain the lower suppression of glucagon secretion after oral than during intravenous glucose administration in healthy humans, as recently reported [36]. Moreover, the lack of increment in plasma glucose concentration in non-diabetic subjects does not imply that the same applies for subjects with impaired glucose tolerance or type 2 diabetes mellitus. Given the loss of insulinotropic action of GIP but preserved stimulatory effect on glucagon secretion, the additional glucagonotropic action of GLP-2 might contribute to the hyperglucagonaemia which characterises type 2 diabetes mellitus [37].

In conclusion, our results suggest that the stimulation of glucagon secretion by GLP-2 is mediated via GLP-2r present in the alpha cell in rats. Based on our analogous immunohistochemical findings in human pancreas, this mode of action may also apply to humans. In view of the ongoing evaluation of GLP-2 as a potential drug candidate for intestinal disorders, further in vivo studies are warranted to assess the importance of its glucagonotropic effect, in particular in subjects with impaired glucose homeostasis, with regard to a possible contribution to the diabetic hyperglucagonaemia.

Acknowledgement This study was supported by grants from the Deutsche Forschungsgemeinschaft (J. de H., HE 3639/1-1), the Danish Medical Research Council, the European Foundation for the Study of Diabetes and the Novo Nordisk Foundation.

Duality of interest The authors declare that there is no conflict of interest associated with this manuscript.

\section{References}

1. Drucker DJ (2002) Gut adaptation and the glucagon-like peptides. Gut 50:428-435

2. Estall JL, Drucker DJ (2006) Glucagon-like peptide-2. Annu Rev Nutr 26:391-411 
3. Sinclair EM, Drucker DJ (2005) Proglucagon-derived peptides: mechanisms of action and therapeutic potential. Physiology (Bethesda) 20:357-365

4. Wallis K, Walters JR, Forbes A (2007) Review article: glucagonlike peptide 2 - current applications and future directions. Aliment Pharmacol Ther 25:365-372

5. Jeppesen PB (2006) Glucagon-like peptide-2: update of the recent clinical trials. Gastroenterology 130:S127-S131

6. Henriksen DB, Alexandersen P, Byrjalsen I et al (2004) Reduction of nocturnal rise in bone resorption by subcutaneous GLP-2. Bone 34:140-147

7. Henriksen DB, Alexandersen P, Hartmann B et al (2007) Disassociation of bone resorption and formation by GLP-2 A 14day study in healthy postmenopausal women. Bone 40:723-729

8. Bell GI, Santerre RF, Mullenbach GT (1983) Hamster preproglucagon contains the sequence of glucagon and two related peptides. Nature 302:716-718

9. Orskov C, Holst JJ, Knuhtsen S, Baldissera FG, Poulsen SS, Nielsen OV (1986) Glucagon-like peptides GLP-1 and GLP-2, predicted products of the glucagon gene, are secreted separately from pig small intestine but not pancreas. Endocrinology 119:1467-1475

10. Schmidt WE, Siegel EG, Creutzfeldt W (1985) Glucagon-like peptide-1 but not glucagon-like peptide-2 stimulates insulin release from isolated rat pancreatic islets. Diabetologia 28:704-707

11. Holst JJ (2004) On the physiology of GIP and GLP-1. Horm Metab Res 36:747-754

12. Orskov C, Holst JJ, Nielsen OV (1988) Effect of truncated glucagon-like peptide-1 [proglucagon-(78-107) amide] on endocrine secretion from pig pancreas, antrum, and nonantral stomach. Endocrinology 123:2009-2013

13. Sorensen LB, Flint A, Raben A, Hartmann B, Holst JJ, Astrup A (2003) No effect of physiological concentrations of glucagon-like peptide- 2 on appetite and energy intake in normal weight subjects. Int J Obes Relat Metab Disord 27:450-456

14. Meier JJ, Nauck MA, Pott A et al (2006) Glucagon-like peptide 2 stimulates glucagon secretion, enhances lipid absorption, and inhibits gastric acid secretion in humans. Gastroenterology 130:44-54

15. Creutzfeldt WO, Kleine N, Willms B, Orskov C, Holst JJ, Nauck MA (1996) Glucagonostatic actions and reduction of fasting hyperglycemia by exogenous glucagon-like peptide I(7-36) amide in type I diabetic patients. Diabetes Care 19:580-586

16. Nauck MA, Heimesaat MM, Orskov C, Holst JJ, Ebert R, Creutzfeldt W (1993) Preserved incretin activity of glucagon-like peptide 1 [7-36 amide] but not of synthetic human gastric inhibitory polypeptide in patients with type-2 diabetes mellitus. $\mathrm{J}$ Clin Invest 91:301-307

17. Nauck MA, Heimesaat MM, Behle K et al (2002) Effects of glucagon-like peptide 1 on counterregulatory hormone responses, cognitive functions, and insulin secretion during hyperinsulinemic, stepped hypoglycemic clamp experiments in healthy volunteers. J Clin Endocrinol Metab 87:1239-1246

18. Meier JJ, Gallwitz B, Siepmann N et al (2003) Gastric inhibitory polypeptide (GIP) dose-dependently stimulates glucagon secretion in healthy human subjects at euglycaemia. Diabetologia 46:798-801

19. Cejvan K, Coy DH, Efendic S (2003) Intra-islet somatostatin regulates glucagon release via type 2 somatostatin receptors in rats. Diabetes 52:1176-1181
20. Strowski MZ, Parmar RM, Blake AD, Schaeffer JM (2000) Somatostatin inhibits insulin and glucagon secretion via two receptors subtypes: an in vitro study of pancreatic islets from somatostatin receptor 2 knockout mice. Endocrinology 141:111-117

21. de Heer J, Holst JJ (2007) Sulfonylurea compounds uncouple the glucose dependence of the insulinotropic effect of glucagon-like peptide 1. Diabetes 56:438-443

22. Sambrook J, Fritsch EF, Maniatis T (1989) Quantitation of DNA and RNA. In: Ford N, Nolan C, Ferguson M (eds) Molecular cloning: a laboratory manual, 2nd edn. Cold Spring Harbor Laboratory Press, Cold Spring Harbor, NY, p E.5

23. Vandesompele J, De Preter K, Pattyn F et al (2002) Accurate normalization of real-time quantitative RT-PCR data by geometric averaging of multiple internal control genes. Genome Biol 3(7): RESEARCH0034.1-11 (Epub 18 June)

24. Pfaffl MW (2001) A new mathematical model for relative quantification in real-time RT-PCR. Nucleic Acids Res 29:e45

25. Orskov C, Hartmann B, Poulsen SS, Thulesen J, Hare KJ, Holst JJ (2005) GLP-2 stimulates colonic growth via KGF, released by subepithelial myofibroblasts with GLP-2 receptors. Regul Pept 124:105-112

26. Brand CL, Jorgensen PN, Knigge U et al (1995) Role of glucagon in maintenance of euglycemia in fed and fasted rats. Am J Physiol 269:E469-E477

27. Orskov C, Jeppesen J, Madsbad S, Holst JJ (1991) Proglucagon products in plasma of noninsulin-dependent diabetics and nondiabetic controls in the fasting state and after oral glucose and intravenous arginine. J Clin Invest 87:415-423

28. Baldissera FG, Munoz-Perez MA, Holst JJ (1983) Somatostatin 1-28 circulates in human plasma. Regul Pept 6:63-69

29. Munroe DG, Gupta AK, Kooshesh F et al (1999) Prototypic G protein-coupled receptor for the intestinotrophic factor glucagonlike peptide 2. Proc Natl Acad Sci U S A 96:1569-1573

30. Yusta B, Huang L, Munroe D et al (2000) Enteroendocrine localization of GLP-2 receptor expression in humans and rodents. Gastroenterology 119:744-755

31. Tang-Christensen M, Larsen PJ, Thulesen J, Romer J, Vrang N (2000) The proglucagon-derived peptide, glucagon-like peptide-2, is a neurotransmitter involved in the regulation of food intake. Nat Med 6:802-807

32. Hartmann B, Johnsen AH, Orskov C, Adelhorst K, Thim L, Holst JJ (2000) Structure, measurement, and secretion of human glucagon-like peptide-2. Peptides 21:73-80

33. Vilsboll T, Krarup T, Deacon CF, Madsbad S, Holst JJ (2001) Reduced postprandial concentrations of intact biologically active glucagon-like peptide 1 in type 2 diabetic patients. Diabetes 50:609-613

34. Deacon CF (2004) Circulation and degradation of GIP and GLP1. Horm Metab Res 36:761-765

35. Hartmann B, Harr MB, Jeppesen PB et al (2000) In vivo and in vitro degradation of glucagon-like peptide-2 in humans. J Clin Endocrinol Metab 85:2884-2888

36. Meier JJ, Deacon CF, Schmidt WE, Holst JJ, Nauck MA (2007) Suppression of glucagon secretion is lower after oral glucose administration than during intravenous glucose administration in human subjects. Diabetologia 50:806-813

37. Vilsboll T, Krarup T, Madsbad S, Holst JJ (2002) Defective amplification of the late phase insulin response to glucose by GIP in obese type II diabetic patients. Diabetologia 45:1111-1119 